\title{
Sexual violence against women and girls in South Sudan
}

\author{
Dilshad Jaff
}

\begin{abstract}
This Letter to the Editor is in reference to the article by Murphy M, Ellsberg M and Contreras-Urbina M, "Nowhere to go: disclosure and help-seeking behaviors for survivors of violence against women and girls in South Sudan," published on 12 February 2020. The authors have to be lauded to study this important topic in South Sudan where data are scarce and the problem is less understood. In such a context, actions by various actors to address sexual violence, a major public health concern and a serious international humanitarian law and human rights violation, must be well thought of to avoid causing more harm and compound the suffering of survivors.
\end{abstract}

Keywords: Sexual violence, Armed conflicts, Complex humanitarian emergencies, Do no harm

\section{Main text}

I found the recent research on disclosure and help seeking behaviors for survivors of violence against women and girls in South Sudan by Murphy M, Ellsberg M and Contreras-Urbina M [1], a praiseworthy contribution to the literature.

Sexual violence, a major public health concern and a serious international humanitarian law and human rights violation, has both short and long term physical and mental consequences. Not only among women and girls, armed conflicts and complex humanitarian emergencies put men and boys within the population at a high risk. While addressing help seeking behaviors for survivors is important, ensuring the continuum of care is critical.

In South Sudan, the youngest country in the world, in addition to the lack of sustainable quality health services, data are scarce and the magnitude of the problem is not even known, much less understood. Therefore, designing and implementing evidence-based interventions tailored to needs in a timely manner is challenging. As a mechanism to overcome that, the International Committee of

Correspondence: jdilshad@email.unc.edu

Maternal and Child Health Department, Gillings School of Global Public Health, University of North Carolina at Chapel Hill, 135 Dauer Drive, Chapel Hill, NC 27599, USA the Red Cross (ICRC) applies a 'reverse burden of proof' in conflict zones, which presumes the occurrence of sexual violence unless proven otherwise. This is enabling the organization to start actions without any delay and ultimately creating more space for survivors to get the necessary help. It is noteworthy to mention that this approach is unique in responding to the needs of the victims within the humanitarian sphere.

It is important to 'making the needs of the invisible, visible' with keeping in mind the 'Do No Harm' principles to ensure that these actions don't cause more harm and compound the suffering of survivors. Protecting the dignity and safety of civilians and victims of armed conflicts is critical. All concerned actors must ensure such practices.

\section{Abbreviation \\ ICRC: The International Committee of the Red Cross}

\section{Acknowledgements}

Not applicable.

\section{Authors' contributions}

The author(s) read andapproved the final manuscript.

\section{Authors' information}

Dilshad Jaff, MD, MPH is an adjunct associate professor and a humanitarian fellow at the Gillings School of Global Public Health. He holds a Master of Public Health degree from the Gillings School and have more than 20 years' 
field experience in complex humanitarian crises working for refugees and IDPs, largely with the International Committee of the Red Cross. He has experience in designing, implementing, supervising and monitoring health projects and programs during and after complex humanitarian emergencies. In addition to his formal studies in medicine and public health, he studied medical microbiology with considerable training in conflict resolution.

\section{Funding}

Not applicable.

Availability of data and materials

Not applicable.

\section{Ethics approval and consent to participate}

Not applicable.

\section{Consent for publication}

Not applicable.

\section{Competing interests}

The authors declare that they have no competing interests.

Received: 21 March 2020 Accepted: 26 March 2020

Published online: 07 April 2020

\section{Reference}

1. Murphy M, Ellsberg M, Contreras-Urbina M. Nowhere to go: disclosure and help-seeking behaviors for survivors of violence against women and girls in South Sudan. Confl Heal. 2020;14:6. https://doi.org/10.1186/s13031-020-0257-2.

\section{Publisher's Note}

Springer Nature remains neutral with regard to jurisdictional claims in published maps and institutional affiliations.

Ready to submit your research? Choose BMC and benefit from:
- fast, convenient online submission
- thorough peer review by experienced researchers in your field
- rapid publication on acceptance
- support for research data, including large and complex data types
- gold Open Access which fosters wider collaboration and increased citations
- maximum visibility for your research: over 100M website views per year
At BMC, research is always in progress.
Learn more biomedcentral.com/submissions

